\title{
Citizenship: A Political or Legal Matter? From Legal - Anthropological Perspective
}

\begin{abstract}
Citizenship is a political as well as legal or a constitutional matter. This is also a social right of a citizen. The status of being a citizen and the quality of persons, works as a member of a community. Without citizenship, one is denied of rights to live, work, vote, pay taxes and many other things related to his or her rights and duties. Consanguineous relationship, jus soli, naturalization and honorary are considered as major categories of citizenship in Nepal.

The citizenship on consanguineous relationship may be linked with the theory of anthropology under the direct line descent, immediate descent, lineal descent, maternal line descent, mediate descent and paternal line descent.

In Nepal, a child of a citizen having obtained the citizenship of Nepal by birth prior to the commencement of the Constitution of Nepal should acquire the citizenship of Nepal by descent, if the child's father and mother (parents) both are citizens of Nepal. Many citizens are in condition of statelessness and deprived of the right to obtain citizenship due to legal, social, administrative, poverty and identities problems of the citizens. Therefore, any citizen of Nepal should not be statelessness or deprived of the right to obtain citizenship on the basis sex, caste, and race, religion social and cultural values.
\end{abstract}

Key words: By Descent, By Birth, Naturalized citizenship, Honorary, Non- Resident, Identity of Descent

\section{Introduction}

The word 'citizenship' is derived from the Latin word for city. People identified themselves as belonging to cities than countries. Therefore, without citizenship in a country, one has no right to live there, work, vote, pay taxes and other duties. In this situation, such person falls under the stateless ${ }^{1}$ category and is forced to live without being able to use basic rights.

Hence, a citizenship is a certificate that a person gets being a genuine member of a Nation. The Black law Dictionary states it as the status of being a citizen and the quality of persons,

\footnotetext{
${ }^{1}$ Stateless situation is the concept of a person lacking belonging to any recognized state. A stateless person is someone having no citizenship or nationality.
} 
conduct as a member of a community. ${ }^{2}$. In this regard, the Universal Declaration of Human Rights has defined it as below:

Everyone has the right to a nationality. No one shall be arbitrarily deprived of his nationality nor denied the right to change his nationality. ${ }^{3}$

The International covenant on Civil and political Rights envisages that, "Every child shall be registered immediately after birth and shall have a name. Every child has the right to acquire a nationality. ${ }^{4}$

Indeed, when a person born in his/her country and gets nationality and citizenship, he or she becomes a member of a nation and can use his or her political, constitutional and legal rights as well as adopting his or her nationality. If you have citizenship, you have a whole set of rights that non-citizen might not have, a citizen without a citizenship has no status and quality in his or her community or nation. In sum up, citizenship is concerned with the nationality rather than legal right

\section{Statement of the Problem}

Patriarchal mindset is obstacle to obtain the right of citizenship by mother to provide on the basis of descent to their children due to existing legal provision. A person who is not a citizen, he or she cannot obtain citizenship of Nepal. Similarly, Nepali women, if she is married to foreigners and berthing to children; permanently residing, and who has not obtained or cannot obtain citizenship on the basis of their father's citizenship but still are unable to obtain Nepali citizenship.

Other hand, people who have been denied citizenship on the basis of sex, gender, ethnicity and other reasons; People who have been living in Nepal for a long time still have not been able to get citizenship. Persons unable to obtain citizenship certificate due to geographical remoteness, administrative difficulties, proposed system of citizenship on the basis of descent. Even, if both mother and father is Nepali, their children will not get citizenship, if both mother and father do not have citizenship and children born out of a mixed marriage. Children of Nepali parents who have not obtained citizenships whereas the paternity is not known.

The certificate of Nepali citizenship should not be revoked in the case of British resident of British Gurkhas enlisting in the army on the basis of the treaty. Even though British retired from the army, they are still Nepali citizens. Prohibition of dual citizenship for all those who obtain a residence visa does not address the various concerns that arise in the country's sovereignty and national security.

2 Bryan A Garner, Black Law Dictionary: Ninth Edition, pp 268

3 Article 15 of Universal Declaration of Human Rights, 1948.

${ }^{4}$ Art. 24 of The International Covenant on Civil and Political Rights, 1966 
Out of that, he seems to have gone to India, Bhutan, Burma, Sikkim, China, etc. through marital relations, while he has migrated to UK and Commonwealth countries as a soldier. The number of Nepalese migrating to different countries of the world in search of opportunities and migrating to the Gulf countries for employment has also been increasing significantly in recent days. People of Nepali origin who migrate abroad in search of talent and educational opportunities are found to be endowed with knowledge, skills, technology and economic advancement.

In recent times, foreigners of Nepali origin and Nepalese living abroad, i.e. non-resident Nepalese citizenship, have also been demanding their identity and facilities in Nepal to be institutional partners in Nepal's development process. In this context, the Non-Resident Nepali Act, 2064 has also been issued to address non-resident Nepalese citizenship in Nepal. The Act was issued with the objective of increasing the proximity of non-resident Nepalese citizenship to Nepal and motivating such persons to participate in the overall development of Nepal.

\section{Objectives of the Study}

Some objectives are drawn as below:

a) To explore the patriarchal mindset an obstacle to obtain the right of citizenship

b) To describe the provision of citizenship issues in the existing legal system

c) To analyze a person whose mother was a citizen of Nepal at his or her birth but could not able to provide a citizenship to her children's.

d) To examine a rigid system of naturalized citizenship to foreign nationals

e) To find out the solution for having easy access to obtain a citizenship of Nepal

\section{Equality, Nationality and Stateless on Citizenship Issues}

The Constitution and Citizenship Act of Nepal states that under the right to equality, all citizens shall be equal before the law and no one shall be deprived of the equal protection of the law. Although women's rights include equal rights without gender discrimination, and under children's rights, every child has the right to a name with their own identity, but these provisions seem to be limited to constitutional documents.

Similarly, the various international human rights conventions of which Nepal is a party have the same right to equal protection under the law, the right to acquire, change or possess the same nationality as a man, the right of a wife not to change her nationality automatically due to her marriage to a foreigner or her husband's nationality

No matter what the husband's nationality is, the right of a woman to wear the nationality of her choice, the same right of a woman as the right of a man to his children, It guarantees 
children the right to be registered at birth, to have their own name and nationality, and to abide by national law and international instruments if children are stateless.

\section{Obligation of International Law}

It is also the responsibility of the Government of Nepal to fulfill the obligations created by international conventions such as non-discrimination on the basis of caste, religion, gender, gender equality and statelessness of children.

The Nepal Treaty Act 1990 also provides that all treaties to which Nepal is a party shall be treated as the national law of Nepal and the provisions of the treaty shall apply in case of conflict with national law and such treaties.

It has been universally accepted that every country pursues a citizenship policy that suits its national interests and national circumstances. According to the same belief, keeping in view the geopolitical situation of the nation, even if a strict policy is adopted, it should be done on the basis of equality.

In the case of a person born in Nepal and residing in Nepal and whose father has not been identified, the mother must apply with the information that the father has not been identified. Apart from the identity and equality of mothers, the law seems to have ridiculed the constitutional provisions of international treaties, conventions and the constitution of Nepal.

\section{Identification of Father and Mother}

According to this provision, no proof of motherhood is required for obtaining citizenship in the name of the father but identification of the father is required for obtaining citizenship in the name of the mother. Due to such provision that if the father cannot be identified, a clear basis has to be given.

This provision makes it mandatory for the father to obtain citizenship, while the woman's own body does not appear to have acknowledged the independent existence of her own rights. This provision is contrary to the principle of non-discrimination.

On the other hand, the bill is silent on the issue of citizenship of children born in foreign lands and women born in foreign lands who are forced to engage in prostitution as a result of foreign employment.

Considering the premise that the constitution does not deprive any Nepali citizen of citizenship, the provision of granting citizenship easily in the name of father or mother by children born to Nepali parents or single parents should also make hesitant to spend money for gender equality. It is to dominate thinking. 


\section{Marital Naturalized Citizenship}

In the case of marital naturalized citizenship, a foreign woman married to a Nepali citizen can obtain Nepali naturalized citizenship, but the provision of not granting citizenship to a foreign man if a Nepali woman wants to stay in Nepal after marrying to a foreigner is also against the principle of non-discrimination.

In the case of a country like ours, a loose policy of citizenship distribution is likely to jeopardize the sovereignty of the country itself.

Giving citizenship to a foreign wife will not affect the sovereignty, geographical integrity and nationality of the country, but giving citizenship to a foreign husband will seriously endanger the sovereignty, geographical integrity and nationality of the country and discriminating between men and women is a violation of international treaties and conventions.

Our neighboring country Bhutan, which has a strict policy on citizenship, has made provision for issuing identity cards with certain rights without envisaging marital adopted citizenship, which can be followed by Nepal to ensure the right to equality between men and women.

Similarly, in the case of granting naturalized citizenship, a residence visa can be issued only after 7 years, as in India, until naturalized citizenship is obtained. In this way, the principle of affidavit can be followed by treating the foreign husband and the foreign wife equally on the basis of marriage.

However, in the case of granting citizenship to foreign husbands on the basis of marriage, since the Constitution does not envisage naturalized citizenship except in the present case.

\section{Categories of the Citizenships}

In the context of Nepal, the Constitution of Nepal has provisioned five categories of the citizenships: (a) Citizenship on Jus- Sagunis or by Descent, (b) Citizenship on Jus- Soli or by Birth, (c) Citizenship on Matrimonial Relation or Naturalization (d) Honorary, and e) Non-resident Nepali citizenship

\section{By Descent}

Descent is related with the blood, it means consanguineous relations of a person with their father and mother. There may be direct line descent, immediate descent, lineal descent, maternal line descent, mediate descent and paternal line descent etc. 
The citizenship by descent is a core feature of the citizenship in Nepal. Nationality is an ethnic, caste, racial and tribal concept. If we could not acquire nationality, we have no right to take citizenship.

The nationality of a person identifies his or her place of birth or country but the citizenship of a person is his or her registration as a citizen by the government of the respective country.

Therefore, without taking nationality, he or she could not acquire the citizenship. Nationality should be obtained through consanguineous relation and inheritance from his or her parents, which is called natural phenomenon.

The constitution of Nepal has assured that no citizen of Nepal may be deprived of the right to obtain citizenship. There is a provision of single federal citizenship with State identity in Nepal.

The persons who have obtained the citizenship of Nepal at the time of commencement of this Constitution and who are qualified to obtain citizenship in accordance with this Part shall be the citizens of Nepal. ${ }^{5}$

Person who has his or her permanent domicile in Nepal at the time of commencement of the Constitution should be the citizen of Nepal by descent: such as (a) a person who has obtained the citizenship of Nepal by descent prior to the commencement of this Constitution, (b) a person whose father or mother was a citizen of Nepal at his or her birth.

Thereof, genuine Nepali citizen should obtain the Nepali citizenship but foreigners can't obtain a Nepalese citizenship. However, in case of a foreigner, by naturalization they can acquire a Nepali citizenship .We can give some examples - What is my nationality? My nationality is Nepali. The right to citizenship does not reflect the values of right to equality as was seen in the case of Benjamin Peter v. Home Ministry ${ }^{6}$. Even though in the name of equality, almost all activists in Nepal are lobbying for providing Nepali citizenship to foreign citizens, they haven’t cared about the real issue of nationality so far.

Different countries have different provisions since it is the matter of nationality .For examples,

In the United States: The right of foreigners to vote has historically been a contentious issue. A foreigner, in this context, is an alien or a person who is not a citizen of the United States. Federal law has prohibited non-citizens from voting in federal elections, punishing them by fines, imprisonment, inadmissibility, and deportation. Naturalization is only the way for the immigrants to become citizens.

\footnotetext{
${ }^{5}$ Art $11(1)$ of the Constitution of Nepal

${ }^{6}$ NKP,749(2048) SC, Nepal
} 
All persons born or adopted in the United States and under its jurisdiction shall be citizens of the United States and of the State in which they reside, and no state shall make or enforce laws that would deprive the rights and privileges of United States citizens.

In India: Citizenship of India by Naturalization can be acquired by a foreigner (not illegal migrant) who is ordinarily resident in India for 12 years (throughout the period of 12 months immediately preceding the date of application and for 11 years in the aggregate in the 14 years preceding the 12 months) and other qualifications as specified in Third Schedule to the Citizen Act, who by Naturalization or registration acquires the citizenship of another country shall cease to be a citizen of India ${ }^{7}$ In India there is no provision of double citizenship in the constitution, If any citizen has acquired the citizenship of another country, he or she shall cease to be a citizen of India on the basis of double citizenship.

Some relevant cases are cited as below: It would be better to make more engaged discussions of the cases.

Advocate Chandra Kanta Gyawali vs. His Majesty the Government of $\mathrm{Nepal}^{8}$ : A writ petition filed at the Supreme Court of Nepal that in case of a person whose father or mother is a citizen of Nepal at his or her birth, mother should be given right to pass citizenship by descent to their children. The Supreme Court found that the clause of the article 11 of the Constitution as discriminatory. Court said that it is the jurisdiction of the Legislature. But, with the decision, a mother is equally eligible to recommend her children to get citizenship by descent. The case now the constitution has granted citizenship from name of his or her mother to their children by descent.

Nakkali Maharjan Vs. Nepal Government ${ }^{9}$

The Supreme Court ordered a mandamus to Kirtipur Municipality to provide a recommendation for citizenship by descent to writ petitioner by the name of father and should not discriminate on the ground of gender and marriage.

Every minor who is found within Nepal and the whereabouts of whose father and mother are not known shall, until the father or the mother of Nepal is traced, shall be provided citizenship by descent. A person who is born in Nepal from a woman who is a citizen of Nepal and has resided in Nepal and whose father is not traced shall be provided with the citizenship of Nepal by descent.

\footnotetext{
${ }^{7}$ Section 9(1) of the act provides that any citizen of India

8 ?????

${ }^{9} 2063$ Bs, writ n. 0089, ordered date, 2065.1. 4.
} 
If such person's mother and father both are citizens of Nepal at the time of acquisition of citizenship, such person born in Nepal may acquire the citizenship of Nepal by descent.

$\underline{\text { Sabina Damai vs. Nepal Government }}{ }^{10}$

The Supreme Court of Nepal issued a Mandamus order to the Government of Nepal that writ petitioner was born to descendent Nepali citizen Ganga Maya Damai, therefore the District Administration Office, should provide a citizenship from the name of her mother in accordance with the law.

Chhabi Peters vs. District Administration Office: ${ }^{11}$ The citizenship of the father was not clear. A child who is found within Nepal is considered to be the child of a Nepalese father if the whereabouts of the father cannot be traced. ${ }^{12}$ In this case, until the father of the child is traced he is deemed to be a Nepalese citizen by descent.

\section{Naturalized Citizenship:}

Another feature of citizenship in the Constitution is the concept of naturalized citizenship.

India: Any person born in India on or after 26 January 1950, but prior to the commencement of the 1986 Act on 1 July 1987, is a citizen of India by birth. A person born in India on or after 1 July 1987 is a citizen of India if either parent was a citizen of India at the time of the birth.

In India, documents such as Voter ID Card and Passport may be considered citizenship proof with the birth certificate and a driving License is no valid proof of citizenship, otherwise he or she could not acquire the citizenship of India whether before or after the government of this constitution, in the form of manner prescribed by the government of the dominion of India or the government of India. Persons voluntarily acquiring citizenship of a foreign State cannot be citizens.

The constitution of Nepal has guaranteed three categories of Naturalized Citizenship in Nepal such as; a foreign woman who has a matrimonial relationship with a citizen of Nepal may, if she wishes, acquire the naturalized citizenship of Nepal as provided for in the Federal law.

A person born from a woman who is a citizen of Nepal and married to a foreign citizen, the person may acquire the naturalized citizenship of Nepal in accordance with the Federal law if he or she has permanently resided in Nepal and has not acquired the citizenship of a foreign country. Government of Nepal may, in accordance with the Federal law, grant the naturalized citizenship of Nepal. A foreign woman who has a matrimonial relationship with

\footnotetext{
${ }^{10}$ 067-wo-0703, Decision date of Supreme Court of Nepal, 2067.

${ }^{11}$ NKP ,Volume 33 , 2049

${ }^{12}$ Dhungel 1998, Commentary on the Nepalese Constitution, pp 89.
} 
a citizen of Nepal, his or her father is held to be a foreign citizen converted into naturalized citizenship. If Nepali woman has married to a foreign citizen.

a) A foreign woman who has a matrimonial relationship

A foreign woman who has a matrimonial relationship with a citizen of Nepal may, if she so wishes, acquire the naturalized citizenship of Nepal as provided for in the Federal Law. ${ }^{13}$ The constitution says 'if she so wishes', otherwise she could not automatically acquire the naturalized citizenship of Nepal.

Except this, a foreign man who has a matrimonial relationship with a woman citizen of Nepal could not acquire the naturalized citizenship of Nepal. But if the federal parliament ratifies a bill against these provisions, then it will automatically be against the spirit of the constitution and any citizen of Nepal may file a petition in the Supreme Court to have this federal law declared void on the ground of inconsistency with the constitution of Nepal. The Supreme Court will declare void on the ground of inconsistency. Therefore, the groom of a foreign citizen should be given naturalized citizenship as foreign woman. It is against the constitution of Nepal. The federal parliament must use their legislative wisdom.

Mira Gurung vs. Department of Immigration: ${ }^{14}$ The Supreme Court had declared inconsistency with the article 9(5) and unconstitutional. The subject was a foreign husband who could not stay in Nepal for more than 4 months in any year. On the other hand, same rule allowed a foreign wife of a native husband to stay. It was a discriminatory clause of Alien Rules 1975 and inconsistent with Article 11.

Benjamin Peter vs. Home Ministry 15

The Supreme Court of Nepal had interpreted that the right to equality is a general provision of the fundamental right but right to citizenship does not reflect the values of the right to equality and cannot be exercised against the citizenship.

The Bill of Citizenship issues related to naturalized citizenship has been sub-legis in the federal parliament. The government of Nepal may grant citizenship accordance with the Federal law, grant the naturalized citizenship of Nepal. It is a matter of federal government. $^{16}$

Likewise, Madhesh centered political parties; Janjatis including other small parties have been criticizing the provision of citizenship from the day of promulgation of the

\footnotetext{
13 Article 11(6) of the Constitution of Nepal.

${ }^{14}$ NKP,2051 volume 35

${ }^{15}$ NKP, 2048, 32, 749

16 Article 11(8) Ibid.
} 
Constitution of Nepal. They are demanding through amendment to the constitution mainly to incorporate two states in Terai and to allow naturalized citizen to be elected, nominated or appointed to the Office of President, Vice-president, Prime Minister, Chief of State, Chief Minister, Speaker of a state, Chief Minister, Speaker of a State Assembly and chief of a security body. ${ }^{17}$

Honorary: The fourth feature of citizenship is an honorary citizenship. The Government of Nepal may, in accordance with the Federal law, grant the honorary citizenship of Nepal. ${ }^{18}$ The honorary citizenship is matter of federal government. Without promulgation of federal law, the federal government could not provide honorary citizenship to the foreigners. Therefore, federal law should be promulgated by the federal parliament. It is concerned with contribution. The government can provide honorary citizenship to those who have made important contributions to Nepal,. In the past, Edmund Hillary was the first foreigner who became the first person of Nepal to get honorary Nepalese Citizenship.

\section{Non Resident Nepalese citizenship:}

The fifth feature of citizenship is Non Resident Nepalese citizenship. The non-residential citizenship of Nepal may be so granted to a person who has acquired the citizenship of a foreign country, has resided in a country other than a member state of the South Asian Association for Regional Cooperation, and who or whose father or mother, grandfather or grandmother was previously a citizen of Nepal by descent or birth but subsequently acquired the citizenship of the foreign country that such person may enjoy economic, social and cultural rights in accordance with the Federal law. ${ }^{19}$

It means without federal law, one could not get non residential citizenship. On the other hand, they have no political rights; it means they cannot cast their vote or stand as candidate. Citizenship with Identity of Descent and Gender: The sixth feature of Citizenship is citizenship with identity of descent and gender. This is guaranteed by this constitution for the first time in Nepal. A person who obtains the citizenship of Nepal by descent in accordance with this Constitution may obtain a certificate of citizenship of Nepal with gender identity by the name of his or her mother or father.

\section{Single Federal Citizenship with State Identity in Nepal:}

The last feature of citizenship is single federal citizenship with state identity in Nepal. Nepal is divided into three tiers of government - federation, state and local level. Definitely, in federal countries, the citizenship matter is a matter of federal government. But in Nepal the constitution of Nepal has included single federal citizenship with state identity in Nepal.

\footnotetext{
${ }^{17}$ Article 289 of the Constitution Nepal

${ }^{18}$ Article 11(9) of the Constitution of Nepal

19 Article 14, IBID.
} 
In the meantime, the Supreme Court of Nepal has stayed the government decision to distribute citizenship certificates without making an amendment to the Citizenship Act. The SC has stayed the government decision to issue citizenship through the circular of the Home Ministry in response to a writ petition filed by senior advocates Bal Krishna Neupane and Borna Bahadur Karki.

\section{Conclusion:}

It is a natural right of every person to obtain citizenship by a citizen who has acquired nationality. Citizenship is the basis on which any person acquires the political rights granted by the state. Since the law on citizenship has a direct impact on the weaker sections of the society, women and children, the law should not allow statelessness to come in the case of such class communities.

It is necessary for Nepali citizens to be able to get citizenship easily and to adopt a provision to prevent non-citizens from getting citizenship. Adopting such a provision, the right to equality ensured by the Constitution of Nepal and the provisions of various human rights conventions of which Nepal is a party is necessary to pass this bill only after adopting the principle of non-discrimination and respecting the identity and equality of mothers.

A genuine citizen of Nepal and who has adopted Nepali Nationality should not be deprived of the rights to obtain citizenship of Nepal. Anyone can obtain Nepali citizenship in the name of his / her mother or father on the basis of gender identity i.e. female, male or third gender. Anyone who has obtained Nepali citizenship on the basis of descent before the promulgation of the constitution, to be able to obtain Nepali citizenship on the basis of gender identity in the name of one's mother or father, i.e. on the basis of female, male or third sex, while foreign woman who want to live in Nepal should get an identity card having rights to economic, cultural rights until she receive naturalized citizenship.

However, the Government of Nepal should not provide a citizenship of Nepal to a foreigner without condition of Nation. But a foreign woman who has a matrimonial relationship with a citizen of Nepal may, if she so wishes, acquires the naturalized citizenship of Nepal as provided for in the Federal Law. The constitution says 'if she so wishes', otherwise she could not automatically acquire the naturalized citizenship of Nepal.

\section{References}

Bryan, A Garner, 2009. Black Law Dictionary: Ninth Edition. WEST, A Thomson Reuters Business Press.

Citizenship Act, 2009 Government of Nepal, Ministry of Law, Justice and Parliament Affairs: Law Books Management Board, Babarmahal Press.

Citizenship Act, 2020 Government of Nepal, Ministry of Law, Justice and Parliament Affairs: Law Books Management Board, Babarmahal Press. 
Patan Pragya (Volume: 6, Number: 1 2020)

Citizenship Act, 2063 Government of Nepal, Ministry of Law, Justice and Parliament Affairs: Law Books Management Board, Babarmahal Press.

Citizenship Draft Bill, 2075. Government of Nepal, Ministry of Law, Justice and Parliament Affairs. Dhungel, Surya and Adhikar, Bipin e.tal. 1998. Commentary on the Nepalese Constitution, DeLF, Lawyer's Inc New Plaza Press.

Gyawali, Chandra Kanta e.tal. 2013. Nationality, Equality Statelessness, Citizenship: Constitutional Lawyers Forum. Kathmandu: Srijana Printing Press.

The constitution of Nepal, 2015. Government of Nepal, Ministry of Law, Justice and Parliament Affairs: Law Books Management Board, Babarmahal Press.

The Interim Constitution of Nepal, 2063 (2007). Government of Nepal, Ministry of Law, Justice and Parliament Affairs: Law Books Management Board, Babarmahal Press.

The Constitution kingdom of Nepal 2047 (1990) Government of Nepal, Ministry of Law, Justice and Parliament Affairs: Law Books Management Board, Babarmahal Press.

The Constitution of Nepal 2019 (1962) Government of Nepal, Ministry of Law, Justice and Parliament Affairs: Law Books Management Board, Babarmahal Press.

The Constitution kingdom of Nepal 2015 (1959) Government of Nepal, Ministry of Law, Justice and Parliament Affairs: Law Books Management Board, Babarmahal Press.

The Interim Government Act 2007 (1952) Government of Nepal, Ministry of Law, Justice and Parliament Affairs: Law Books Management Board, Babarmahal Press.

The Government Act 2004 (1948) Government of Nepal, Ministry of Law, Justice and Parliament Affairs: Law Books Management Board, Babarmahal Press.

Section 9(1) of the act provides that any citizen of India

\section{Conventions}

Universal Declaration of Human Rights 1948

International Covenant on Economic, Social and Cultural Rights, 1966

International Covenant on Civil and Political Rights, 1966

Convention on the Elimination of All Forms of Discrimination Against Women, 1979

Cases

NKP, 749 (2048) SC, Nepal

NKP, 2051 volume 35

NKP, Volume 33, 2049

Sabina Damai v. Nepal Government (067-wo-0703, Decision date of Supreme Court of Nepal, 2067.)

Benjamin Peter v. Home Ministry, NKP, 2048, 32, 749

Nakkali Maharjan V. Nepal Government 2063 Bs, writ n. 0089, ordered date, 2065.1. 4.

United States v. Cruikshank, 92 US 542(1875) cited by Dhungel and Adhikari Commentary on the Constitution pp. 84.

Afroyim v. Rusk, 387 U.S. 253 (1967)

Cyrus Vance v. Laurence j. Terranzas 